\title{
Incorporation of management teaching into medical school curricula: a medical student's perspective
}

\author{
Harun Abdul Jalil' \\ Amin Habib ${ }^{2}$
}

Ali Shah ${ }^{2}$

'School of Medicine, Keele University, Keele, Newcastle ST5 5BG, UK;

${ }^{2}$ School of Medical Education, King's

College London, London, UK
Correspondence: Harun Abdul Jalil School of Medicine, David Weatherall Building, University Road, Keele University, Staffordshire, ST5 5BG, Newcastle, UK

Emailv6y05@students.keele.ac.uk
This article was published in the following Dove Press journal: Advances in Medical Education and Practice

\section{Dear editor,}

We read with interest the article by Rouhani et al ${ }^{1}$ regarding UK medical students' perceptions of medical leadership and clinical managers. As fourth year medical students, it comes as no surprise to us that a majority of medical students feel that there is a clear dearth of leadership training in the UK medical curriculum. A systematic review by Abbas et $\mathrm{al}^{2}$ on the attitudes of students toward medical leadership corroborates the findings by Rouhani et al, further emphasizing the lack of medical management teaching. As such, we hope to share our own views on how such teaching should be integrated into current medical curricula.

While the unanimity of Rouhani et al's $\mathbf{s}^{1}$ research conclusion is hard to question, there is a clear appreciation of the barriers to incorporating medical management teaching into the medical curriculum. We particularly agree with a lack of curriculum time being a key barrier to the incorporation of medical management teaching. At present, our timetables allow for very little teaching time in addition to the current curricular aims. However, an area where we believe medical management teaching could be incorporated is the student-selected components (SSCs). SSCs allow students to pursue interests which often do not fall under the standard syllabus. The provision of medical management SSCs would allow students to gain an insight into the management field.

The authors suggest that implementing formative assessments would be helpful in developing leadership skills in medical students. We believe that due to the time constraints present within the medical curriculum, such an approach would not be favorable. Furthermore, in our experience, formative assessments tend to be seen as superfluous by many students whose primary concern is clinical learning that is relevant to their final exams.

A report by the $\mathrm{GMC}^{3}$ has highlighted that management and leadership competencies were key skills that newly qualified doctors felt concerned about in their own clinical practice. We would echo this sentiment and believe this to be partly because our teaching is largely based on guidelines. In other words, we are taught to make guideline-based decisions and hence would feel uncomfortable in medical management situations that tend to fall outside of linear guidelines. From our own experience, teaching methods that afford medical students limited responsibilities in clinical decision making, which are then vetted by senior clinicians, greatly improve confidence. An example of this would be in the general practitioner setting, where medical students are encouraged to see their 
own patients, make a diagnosis, and complete a management plan pending approval from a senior general practitioner. This approach could be translated to medical management, wherein students are given limited responsibility for decision making under tutelage from those within the field.

In conclusion, we wholeheartedly agree with the authors' conclusion regarding the need for medical management education in the medical curricula. In order to achieve this, we recommend the implementation and encouragement of medical management-based SSCs. In addition, we suggest allowing medical students to make limited medical management decisions in order to foster confidence in leadership competencies.

\section{Disclosure}

The authors report no conflicts of interest in this communication.

\section{References}

1. Rouhani MJ, Burleigh EJ, Hobbis C, et al. UK medical students' perceptions, attitudes, and interest toward medical leadership and clinician managers. Adv Med Educ Pract. 2018;9:119-24.

2. Abbas MR, Quince TA, Wood DF, Benson JA. Attitudes of medical students to medical leadership and management: a systematic review to inform curriculum development. BMC Med Educ. 2011;11(1):93.

3. GMC. Be prepared: are new doctors safe to practise? 2014. Available from: https://www.gmc-uk.org/Be_prepared_are_new_doctors_safe_to_ practise_Oct_2014.pdf_58044232.pdf. Accessed March 13, 2018.

Dove Medical Press encourages responsible, free and frank academic debate. The content of the Advances in Medical Education and Practice 'letters to the editor' section does not necessarily represent the views of Dove Medical Press, its officers, agents, employees, related entities or the Advances in Medical Education and Practice editors. While all reasonable steps have been taken to confirm the content of each letter, Dove Medical Press accepts no liability in respect of the content of any letter, nor is it responsible for the content and accuracy of any letter to the editor.

\section{Publish your work in this journal}

Advances in Medical Education and Practice is an international, peerreviewed, open access journal that aims to present and publish research on Medical Education covering medical, dental, nursing and allied health care professional education. The journal covers undergraduate education, postgraduate training and continuing medical education including emerging trends and innovative models linking education, research, and health care services. The manuscript management system is completely online and includes a very quick and fair peer-review system. Visit http://www.dovepress.com/testimonials.php to read real quotes from published authors.

Submit your manuscript here: http://www.dovepress.com/advances-in-medical-education-and-practice-journal 